\title{
Molybdenum assimilation by cyanobacteria and phytoplankton in freshwater and salt water
}

\author{
Jonathan J. Cole and Judith M. Lane \\ Institute of Ecosystem Studies, Cary Arboretum, Millbrook, New York 12545
}

Roxanne Marino and Robert W. Howarth

Section of Ecology and Systematics, Cornell University, Ithaca, New York 14853

\begin{abstract}
We measured the uptake rate of molybdate and related kinetic parameters for nine taxa of cyanobacteria and for the natural phytoplankton communities of six freshwater lakes containing planktonic $\mathrm{N}_{2}$-fixing cyanobacteria. Molybdate uptake followed saturation kinetics and was competitively inhibited by both tungstate and sulfate. Tungstate inhibited molybdate uptake in a nearly mole-for-mole fashion; inhibition constants $\left(K_{i}\right)$ were in the same concentration range (10-30 nM) as the half-saturation constants for molybdate uptake $\left(K_{m}\right)$. Sulfate also inhibited molybdate uptake, but this inhibition was much less specific. The $K_{i}$ for sulfate was in the $\mathrm{mM}$ range-three orders of magnitude above the $K_{m}$ for molybdate uptake. Despite these high $K_{i}$ values, however, sulfate can be an important inhibitor of molybdate uptake in many natural waters as sulfate concentrations are usually some 4-6 orders of magnitude greater than molybdate concentrations. At ambient sulfate and molybdate concentrations in most freshwater lakes, molybdate uptake would be inhibited by $1-5 \%$ due to sulfate. In marine and estuarine systems this inhibition would be $15-20 \%$ and in some saline lakes could be $>70 \%$.
\end{abstract}

Molybdenum is one of the essential cofactors for the vast majority of known $\mathrm{N}_{2}$-fixation systems and many nitrate reductase systems (Fogg and Wolfe 1954; Manheim and Landergren, 1978; Robson et al. 1986). The function of Mo in both nitrogenase and nitrate reductase, as well as in several other enzyme systems such as formate dehydrogenase, is that it assists in the catalysis of the transfer of two, or a multiple of two, electrons to or from the substrate (Pope et al. 1980). The Mo requirements for nitrogenase activity exceed those for nitrate reductase (Fogg and Wolfe 1954).

In oxic natural waters Mo is thought to be present primarily as the oxyanion, $\mathrm{MoO}_{4}{ }^{2-}$, and its concentration ranges from $\sim 1$ to $\sim 100$ $\mathrm{nM}$ in most environments (Howarth et al. $1988 b$; Marino et al. 1990). For an organism to synthesize an active nitrogenase enzyme, it must first be able to transport $\mathrm{MoO}_{4}{ }^{2-}$ from

\footnotetext{
${ }^{1}$ Present address: Hart Road, Conway, Massachusetts 01341.

\section{Acknowledgments}

This paper is a contribution to the program of the Institute of Ecosystem Studies.

Financial support was provided by the Ecosystem Studies Program of the National Science Foundation (BSR 86044688 and BSR 89-05364) and by the Institute of Ecosystem Studies.
}

the environment at the ambient concentration and must be able to do so in the presence of potential inhibitors or competitors of this transport which are also present in natural waters. One potential competitive inhibitor to $\mathrm{MoO}_{4}{ }^{2-}$ uptake is $\mathrm{SO}_{4}{ }^{2-}$. Sulfate resembles closely molybdate in terms of size, charge, and stereochemistry and is present in natural environments at concentrations some 4-6 orders of magnitude greater than molybdate.

Howarth and Cole (1985) proposed a twopart hypothesis concerning the interaction between sulfate and molybdate and its ecological significance. First, $\mathrm{SO}_{4}{ }^{2-}$ is a competitive inhibitor of $\mathrm{MoO}_{4}{ }^{2-}$ transport that lowers significantly the uptake of $\mathrm{MoO}_{4}{ }^{2-}$ at ambient $\mathrm{SO}_{4}{ }^{2-}$ and $\mathrm{MoO}_{4}{ }^{2-}$ concentrations. Second, this interaction lowers the availability of $\mathrm{Mo}$ to $\mathrm{N}_{2}$-fixing organisms and may limit the rate of $\mathrm{N}_{2}$ fixation in environments such as coastal waters, where the $\mathrm{SO}_{4}{ }^{2-}: \mathrm{MoO}_{4}{ }^{2-}$ ratio is large. Thus, this interaction between molybdate and sulfate could be one of the factors (e.g. Paerl et al. 1987; Paulsen et al. 1992; Vitousek and Howarth 1991) contributing to the switch in phytoplankton nutrient limitation from $P$ to $\mathrm{N}$ along salinity gradients (Caraco et al. 1987; Howarth et al. 1988b). The present paper addresses only the first part of the hypothesis. For the second part, we refer the reader else- 
Table 1. Freshwater lakes used to measure molybdate uptake.

\begin{tabular}{|c|c|c|c|c|c|}
\hline Lake & Location & Sulfate $(\mathrm{mM})$ & Molybdate (nM) & Chl $\left(\mu \mathrm{g} \mathrm{liter}^{-1}\right)$ & $\begin{array}{c}\mathrm{N}_{2} \text { fixation } \\
\text { (nmol ethylene } \\
\text { liter-1 } \mathrm{h}^{-1} \text { ) }\end{array}$ \\
\hline Chodikee & $41^{\circ} 45^{\prime} \mathrm{N}, 73^{\circ} 55^{\prime} \mathrm{W}$ & 0.03 & 0.94 & 60 & $>100$ \\
\hline Mirror & $43^{\circ} 57^{\prime} \mathrm{N}, 71^{\circ} 42^{\prime} \mathrm{W}$ & 0.04 & 0.05 & 1 & 0 \\
\hline Copake & $42^{\circ} 10^{\prime} \mathrm{N}, 73^{\circ} 30^{\prime} \mathrm{W}$ & 0.08 & 3.75 & 40 & $10-100$ \\
\hline Taghkanic & $42^{\circ} 07^{\prime} \mathrm{N}, 73^{\circ} 35^{\prime} \mathrm{W}$ & 0.10 & 1.98 & 7 & $10-100$ \\
\hline Stissing & $41^{\circ} 50^{\prime} \mathrm{N}, 73^{\circ} 37^{\prime} \mathrm{W}$ & 0.24 & 15.6 & 12 & 0 \\
\hline Oneida & $43^{\circ} 00^{\prime} \mathrm{N}, 75^{\circ} 52^{\prime} \mathrm{W}$ & 0.46 & 4.17 & 17 & $1-10$ \\
\hline
\end{tabular}

where (e.g. Paerl et al. 1987; Howarth et al. 1988 ; Marino et al. 1990; Vitousek and Howarth 1991; Paulsen et al. 1992).

In previous work dealing with the first part of our hypothesis, we reported direct measurements of the kinetics of Mo uptake for only a single freshwater lake (Howarth and Cole 1985; Cole et al. 1986). Here we investigate the kinetics of Mo transport and its inhibition by sulfate and tungstate (a better known competitive inhibitor of molybdate transport in bacteria) for various cyanobacterial cultures and natural phytoplankton communities from a series of freshwater lakes, estuaries, and marine systems. We revise, substantially, our prior estimates of the kinetic parametcrs, $V_{\max }$, $K_{m}$, and $K_{i}$ by working with ${ }^{99}$ Mo of higher specific activity, allowing us to make measurements in the ambient concentration range.

\section{Methods}

Field sampling procedure-For experiments with the natural plankton communities of lakes, we collected 20 liters of water in an acid-washed polycarbonate container with a peristaltic pump. Sampled this way, the water contacted no metallic materials. Samples were generally collected late in the day and held in the incubator overnight at $\pm 2^{\circ} \mathrm{C}$ of ambient temperature with a $12: 12 \mathrm{~L} / \mathrm{D}$ cycle before beginning the experiments. The lakes sampled, their locations, and some of their characteristics are shown in Table 1.

Dissolved Mo analysis-We opcrationally define dissolved Mo as the total Mo that passed a Whatman GF/F filter. Concentrations of dissolved Mo were measured by graphite-furnace atomic absorption spectrophotometry (Marino et al. 1990). Dissolved Mo concentrations were measured both to determine the actual specific activity of purchased $\left[{ }^{99} \mathrm{Mo}\right] \mathrm{Na}_{2} \mathrm{MoO}_{4}$ and the ambient levels in the natural systems. For natural systems molybdate was concentrated, if necessary, by coprecipitation with hydrated Mn oxide or by evaporation in a closed system (Marino et al. 1990); stock solutions were run without preconcentration.

Algal cultures - We cultured cyanobacteria taxa originating in freshwater and salt water and kept them in media to which no combined nitrogen was added and which had low initial concentrations of sulfate $(10-30 \mu \mathrm{M})$ and molybdate $(\sim 0.1-1 \mathrm{nM})$. Although planktonic marine cyanobacteria that fix nitrogen are rarely encountered in most environments (Paerl 1988; Howarth 1988; Howarth et al. 1988a), we obtained cultures of benthic and planktonic marine cyanobacteria from various sources (Table 2). Because individual taxa had different requirements for growth, we used several different media (Table 2). We modified media from Gorham-2 (Gorham et al. 1964), K\&M (Kratz and Myers 1955), and F/2 (Guillard 1975). In all cases the modifications were designed to delete all combined nitrogen sources, reduce Mo in the trace metal solutions so that estimated final Mo concentrations were $<1$ $\mathrm{nM}$, and replace $\mathrm{SO}_{4}{ }^{2-}$ salts with $\mathrm{Cl}^{-}$salts to maintain $\mathrm{SO}_{4}{ }^{2-}$ at $<30 \mu \mathrm{M}$. Most taxa were fixing nitrogen during the experiments.

Algal biomass and nitrogenase activityChlorophyll concentrations were measured fluorometrically in basic methanol extracts (Holm-Hansen and Riemann 1978) with a Turner Designs fluorometer calibrated with both purified chlorophyll (Sigma Chemical Co.) and samples measured spectrophotometrically (in acetone). Particulate $\mathrm{C}$ and $\mathrm{N}$ concentrations were measured on filtered samples (Gelman $\mathrm{A} / \mathrm{E}$ ) with a Carlo-Erba CNS analyzer.

The presence of nitrogenase activity in the cultures and water samples was determined by acetylene reduction (Stewart et al. 1967). 
Table 2. Algal cultures used in the Mo uptake experiments. The cultures had various origins. We obtained Anabaena oryzae (A15), Nodularia harveyana (NODH2), and Oscillatoria woronichinii (CSIRO-52) from the Australian Collection for Marine Microorganisms and Anabaena cylindrica (UTEX B1611) from the collection at the University of Texas. E. Graneli provided Nodularia spumigena from the Baltic. Nodularia sp. came from a mixed culture from Pyramid Lake provided by D. Galat. We isolated Calothrix sp. and Phormidium sp. from Narragansett Bay. Trichodesmium sp. (NIBB-1067) was isolated from seawater by K. Ohki and colleagues (see Ohki et al. 1986).

\begin{tabular}{|c|c|c|c|}
\hline Taxon & Media* & $\begin{array}{c}\mathrm{N}_{2} \text { fixation } \\
\text { (nmol ethylene } \\
\left.\text { liter }{ }^{-1} \mathrm{~h}^{-1}\right)\end{array}$ & Chl ( $\mu$ g liter $\left.{ }^{-1}\right)$ \\
\hline O. woronichinii (brackish/coastal) & G-2; $27 \%$ & $1-10$ & 85 \\
\hline Calothrix sp. (coastal marinc) & $\mathrm{G}-2 ; 27 \%$ & $1-10$ & $60-90$ \\
\hline Phormidium sp. (coastal marine) & $\mathrm{G}-2 ; 27 \%$ & $10-100$ & 164 \\
\hline A. oryzae (estuarine) & $\mathrm{G}-2+0.1 \% \mathrm{SW}$ & $>100$ & $88-177$ \\
\hline N. spumigena (Baltic) & $\mathrm{K} \& \mathrm{M} ; 12 \%$ & $>100$ & $44-69$ \\
\hline N. harveyana (Harvey-Peel estuary) & $\mathrm{K} \& \mathrm{M} ; 12 \%$ & $10-100$ & $42-50$ \\
\hline Nodularia sp. (Pyramid Lake) & $\mathrm{G}-2 ; 10 \%$ & 0 & 172 \\
\hline A. cylindrica (freshwaters) & $\mathrm{G}-2 ; 0 \%$ & $>100$ & $21-190$ \\
\hline Trichodesmium sp. (Izu peninsula, Japan) & Mod. F/2;30\%o & 0 & 119 \\
\hline
\end{tabular}

* G-2 is modified from Gorham-2 after Gorham et al. 1964; K\&M is modificd from Kratz and Myers (1955); Mod. F/2 is modificd from Guillard (1975). Modifications are given in text. In the sole case of $A$. oryzae it was necessary to add $0.1 \%$ of Sargasso seawater to maintain growth.

Mo uptake kinetics-We examined the rate of incorporation of ${ }^{99}[\mathrm{Mo}] \mathrm{Na}_{2} \mathrm{MoO}_{4}$ into particulate material for a range of natural plankton communities and for a variety of freshwater and salt-water cyanobacteria. The methods largely followed those of Cole et al. (1986) except that we used ${ }^{99}$ Mo at extremely high specific activity $\left(>1,000 \mathrm{mCi}^{-1} \mathrm{Mo}\right)$ and extremely high purity (special order from New England Nuclear), which allowed us to measure uptake accurately at naturally occurring molybdate concentrations.

Stock solutions of radioactive molybdate were diluted upon receipt with distilled-deionized water that had been autoclaved, and the diluted stock was filtered twice through 0.22 $\mu \mathrm{m}$ pore-size Millipore filters to remove particulate contaminants. To measure the kinetic parameters for molybdate assimilation, we incubated samples $(150-240 \mathrm{ml})$ in $240-\mathrm{ml}$ polycarbonate flasks with a range of $\mathrm{Na}_{2} \mathrm{MoO}_{4}$ concentrations, usually from tracer amounts to $\sim 200 \mathrm{nM}$ (about twice the concentration in seawater) at eight concentration increments. Incubations were done in an incubator at $20^{\circ} \mathrm{C}$ for the cultures and within $2^{\circ} \mathrm{C}$ of ambient temperature for the lake samples. We used "coolwhite" fluorescent lighting at 300-400 $\mu$ Einst $\mathrm{m}^{-2} \mathrm{~s}^{-1}$, and the samples were agitated continuously on a shaker table at 30-60 rpm. Incubation time ranged from 1 to $10 \mathrm{~h}$. Incubations were stopped by adding $2 \mathrm{ml}$ of $4 \mathrm{M}$ nonradioactive $\mathrm{Na}_{2} \mathrm{MoO}_{4}$ to give a final concentration of $30-50 \mathrm{mM}\left(\sim 10^{5}\right.$ times the con- centration of the highest assayed molybdate concentration) depending on the volume of the incubation.

Immediately thereafter, the samples were filtered through $25-\mathrm{mm}$ Gelman A/E filters that had been pretreated by soaking in $1 \mu \mathrm{M}$ $\mathrm{Na}_{2} \mathrm{MoO}_{4}$ to minimize sorption problems (Cole et al. 1986). The amount of radioactivity on each filter was measured by liquid scintillation counting with Scintiverse-II and a Beckman LS-1801 scintillation counter. Quenching was determined by $\mathrm{H}$ number. We waited $40 \mathrm{~h}$ after the end of the incubation so that excess ${ }^{99} \mathrm{Tc}$ would decay before scintillation counting (Elliott and Mortensen 1975); all samples were counted twice (about one half-life apart, $67 \mathrm{~h}$ ) to ensure that the decay rate was identical to that for ${ }^{99} \mathrm{Mo}$.

To measure kinetic inhibition by either sulfate or tungstate, we tested the eight molybdate concentrations (above) against three or six concentrations of $\mathrm{Na}_{2} \mathrm{SO}_{4}$ or $\mathrm{Na}_{2} \mathrm{WO}_{4}$ to create a matrix of 24 or 48 pairs of substrate and inhibitor concentrations for each inhibitor. For sulfate, the concentrations ranged from low amounts $(\sim 1 \mu \mathrm{M})$ to values typical for dilute freshwaters $(\sim 30 \mu \mathrm{M})$ and up to near seawater values $(27 \mathrm{mM})$. For tungstate, we varied concentrations from zero to $\sim 200 \mathrm{nM}$.

Several types of controls were run for the experiments. For each experiment, as an abiotic control, we heat-killed $\left(80^{\circ} \mathrm{C}, 2 \mathrm{~h}\right)$ samples and incubated them as above. For most experiments we also incubated samples in the 


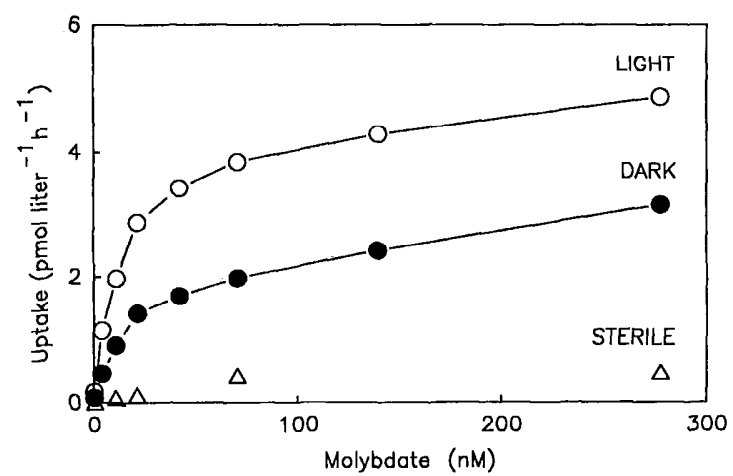

Fig. 1. Uptake of molybdate as a function of molybdate concentration for Anabaena cylindrica, a freshwater $\mathrm{N}_{2}$-fixing cyanobacterium growing in G-2 media. The culture was kept at exponential growth at a Chl $a$ concentration of $35 \mu \mathrm{g} \mathrm{liter}{ }^{-1}$ and was fixing nitrogen (360 nmol ethylene liter $\left.{ }^{-1} \mathrm{~h}^{-1}\right)$. Treatments: light-O; dark-O; after heat killing-A. For the experiment in the light, $K_{m}$ was $12.3 \mathrm{nM}$ and $V_{\max }$ was $4.85 \mathrm{pmol} \mathrm{liter}^{-1} \mathrm{~h}^{-1}$ or $0.14 \mathrm{pmol}$ $(\mu \mathrm{g} \mathrm{Chl} a)^{-1} \mathrm{~h}^{-1}$.

dark to retard growth. Finally, to determine whether either the substrate or inhibitors were affecting growth rate during the incubation and to determine the effect of darkness on growth, we measured the rate of $\mathrm{NaH}^{14} \mathrm{CO}_{3}$ incorporation for each experiment at a range of substrate and inhibitor concentrations.

Calculation of kinetic parameters - The uptake of a substrate, if it follows saturation kinetics can be described by the Michaelis-Menten equation:

$$
v=V_{\max } \times S /\left(K_{m}+S\right)
$$

where $v$ is the uptake rate, $V_{\max }$ the uptake rate at saturating concentrations of the substrate $(S)$, and $K_{m}$ the half-saturation constant. In the absence of known inhibitors, we calculated $V_{\max }$ and $K_{m}$ by linearizing the data according to the familiar Lineweaver-Burke double-reciprocal method (Rudolph and Fromm 1983) and performing linear regressions (but see the objections to this approach by Currie 1982).

An inhibitor for the above reaction, if it is competitive, has no effect on $V_{\max }$, but would affect Eq. 1 as follows:

$$
v=V_{\max } \times S /\left[K_{m} \times\left(1+I / K_{i}\right)+S\right]
$$

where $I$ is the concentration of the inhibitor and $K_{i}$ the constant of inhibition. In experi- ments in which we used one or two concentrations of the inhibitor, the same double-reciprocal plotting procedure could be adopted and $K_{i}$ could be calculated from the change in slope of the double-reciprocal plot. In experiments in which we used multiple levels of inhibitor, we obtained initial estimates of $V_{\max }$ and $K_{m}$ from the no-inhibitor treatment and then by means of a modified Marquardt procedure (Statistical Graphics Corp. 1987) computed the $K_{i}, K_{m}$, an $V_{\max }$ that best fit the data given the initial constraints on $K_{m}$ and $V_{\max }$.

The kinetic parameters we report for the natural systems are apparent averages for the entire algal community because we do not know which organisms accomplished the uptake. Nevertheless, the parameters would adequately describe uptake in those systems.

\section{Results}

Molybdate uptake and controls - In all of the experiments we performed with cyanobacteria, the uptake of molybdate was a hyperbolic function of the molybdate concentration that could be readily described by the familiar Michaelis-Menten model of saturation kinetics (Fig. 1). In two experiments, both with marine diatoms, variance made application of any model impossible and we do not consider these experiments further here. In every experiment we performed, the uptake of molybdate was reduced to negligible levels in heat-killed cultures, indicating that uptake required living cells and suggesting active mediation. Uptake was also reduced (by $50 \%$ or more) for cells incubated in the dark (Fig. 1).

For the 27 lakes and cultures we investigated, the kinetic parameters varied considerably and independently. $K_{m}$ varied from 0.7 to 199 $\mathrm{nM}$ and averaged $28 \pm 7.6 . V_{\max }$ varied from 0.008 to $1.4 \mathrm{pmol} \mathrm{Mo}(\mu \mathrm{g} \mathrm{Chl} a)^{-1} \mathrm{~h}^{-1}$; it averaged $0.26 \pm 0.06$. Thus, although the total range was large for both $K_{m}$ and $V_{\max }$, each had a relatively low C.V. across organisms and environments.

Although the variation in $V_{\max }$ did not appear systematic, some of the variability in $K_{m}$ could be explained by the environmental concentration of Mo from which the sample was drawn (Fig. 2). The algal communities from freshwater lakes or cultures from freshwaters (relatively low Mo environments) generally had 


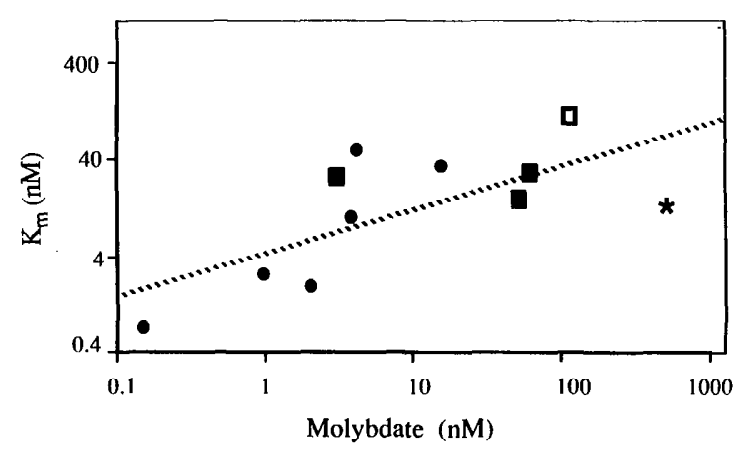

Fig. 2. Affinity constants $\left(K_{m}\right)$ for systems for which we have data. Freshwater lakes-o; cultures from freshwater, estuarine, and marine systems $-\square$. Note: the culture from Pyramid Lake (*) was plotted at the molybdate concentration reported for that lake by Howarth et al. (1988b) but is based on a single sample and may be in error. $\square-$ The benthic cyanobacterium, Calothrix. Equation for line is $\log K_{r n}=0.415 \times \log \left[\mathrm{MoO}_{4}{ }^{2-}\right]+0.68 ; R^{2}=0.43$.

a lower $K_{m}$ (higher affinity for Mo) than did marine or estuarine cultures. There was a significant positive relationship between $\log K_{m}$ and $\log [\mathrm{Mo}]$ (Fig. $2 ; r^{2}=0.43 ; P<0.05$ ). To obtain this relationship for the freshwater lakes we used the measured Mo concentration; for the cultures we used the Mo concentration from the system in which the culture originated (when it was known); for the isolates of unknown freshwater, estuarine, or marine origin, we used the average Mo concentration for those environments. This relationship is curvilinear (on an arithmetic scale) so that $K_{m}$ does not increase as rapidly as does the concentration of Mo.

Inhibition by tungstate - Tungstate inhibited the rate of molybdate transport in every experiment (Figs. 3, 4). The inhibition could be very adequately described by conventional competitive inhibition models. For example, Lineweaver-Burke plots of the kinetic data revealed that tungstate increased the apparent $K_{m}$ but had little or no effect on $V_{\max }$ (Figs. 3, 4). Photosynthesis was not affected by the addition of tungstate in this range (0-200 nM), so the results strongly support the hypothesis that tungstate is a competitive inhibitor of molybdate transport and that the transport mechanism does not discriminate well between tungstate and molybdate. In our 12 experiments, the $K_{i}$ for tungstate (constant of inhibition) ranged from 2 to $200 \mathrm{nM}$ and averaged
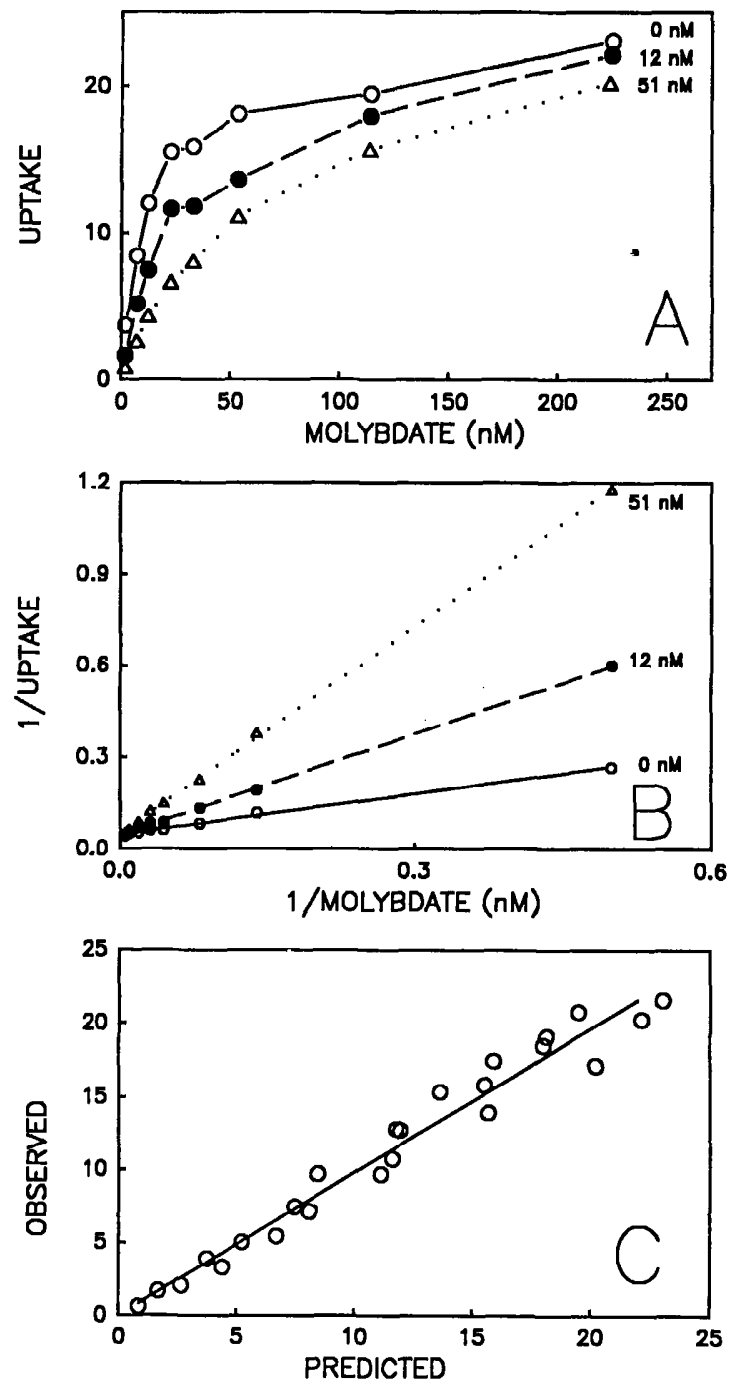

Fig. 3. Uptake of molybdate as a function of molybdate concentration for an estuarine cyanobacterium, $A n$ abaena oryzae, in the presence of three levels of sodium tungstate. $A$. oryzae was maintained in G-2 media plus $0.1 \%$ seawater; salinity was adjusted to $6 \%$ with $\mathrm{NaCl}$. The culture was kept at a chlorophyll concentration of 34 $\mu \mathrm{g} \mathrm{liter}^{-1}$ and was fixing nitrogen $\left(93 \mathrm{nmol}\right.$ ethylene liter ${ }^{-1}$ $\left.\mathrm{h}^{-1}\right)$. A. Uptake rate (pmol Mo liter $\left.{ }^{-1} \mathrm{~h}^{-1}\right)$ as a function of molybdate concentration. B. Lineweaver-Burke plot of the data from panel A. C. Predicted uptake of Mo (using the kinetic constants obtained in panel B) plotted against the observed rate for all three tungstate concentrations simultaneously. Best-fit kinetic parameters are $K_{m}=9.5$ $\mathrm{nM} \mathrm{MoO}{ }_{4}^{2-}, V_{\max }=22.5 \mathrm{pmol}^{2}$ liter $^{-1} \mathrm{~h}^{-1}$, and $K_{i}-\mathrm{W}=$ $8 \mathrm{nM} \mathrm{WO}_{4}{ }^{2-}$. 

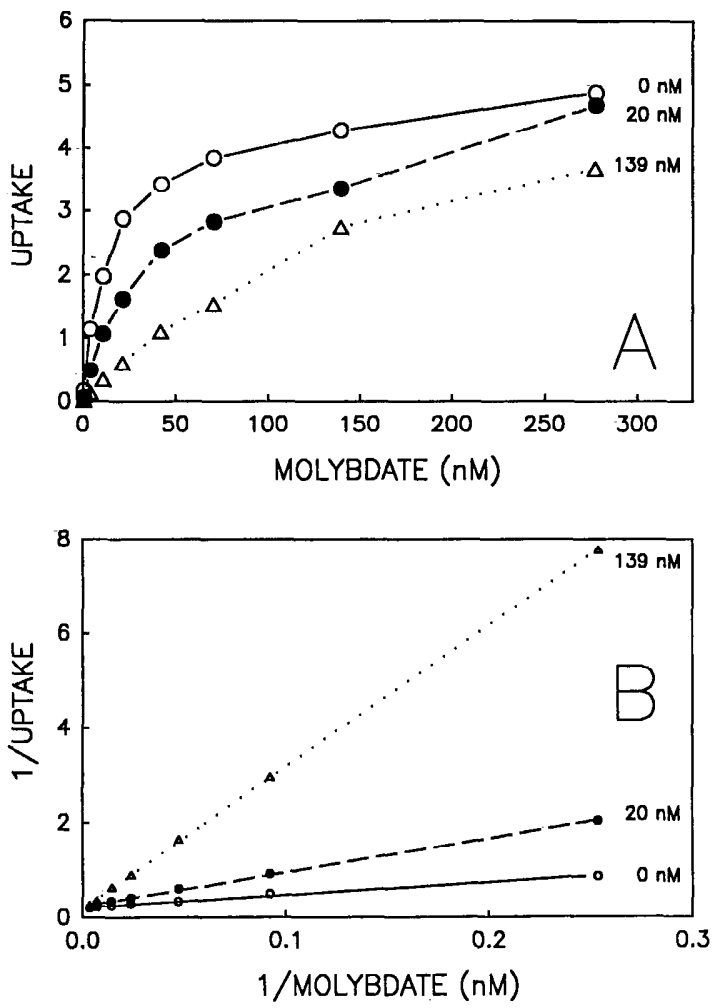

Fig. 4. Uptake of molybdate as a function of molybdate concentration for a freshwater cyanobacterium, $A n$ abaena cylindrica, cultured as in Fig. 1 , in the presence of three levels of sodium tungstate. A. Uptake rate (pmol Mo liter ${ }^{-1} h^{-1}$ ) as a function of molybdate concentration. B. Lineweaver-Burke plot of data in panel $\mathrm{A}$.

$44 \pm 17$. Thus, the range of $K_{i}$ for tungstate was essentially the same as the range of $K_{m}$ for molybdate transport. The $K_{i}$ for tungstate was broadly correlated with $K_{m}(P<0.01)$ and a linear regression of $K_{i}$ against $K_{m}$ had a slope of $0.6 \mathrm{~nm} \mathrm{~nm}^{-1}\left(r^{2}=0.89, P<0.01\right)$, suggesting that the uptake system has similar affinity for tungstate and molybdate.

Inhibition by sulfate-As in the case of tungstate, the inhibition of molybdate uptake by sulfate could also be adequately described by competitive inhibition models. Again, shortterm photosynthesis was not greatly affected by sulfate additions over the range of interest $(0.03-27 \mathrm{mM})$. Unlike tungstate, sulfate was a poor inhibitor of molybdate uptake in the $\mathrm{nM}$ or $\mu \mathrm{M}$ range. In all cases, we did not measure significant inhibition until sulfate reached the mM range (Figs. 5, 6). The $K_{i}$ for sulfate $\left(K_{i}-\right.$ S) ranged from 1.2 to $65 \mathrm{mM}$ for the 19 experiments we performed and averaged $10 \pm 3$.
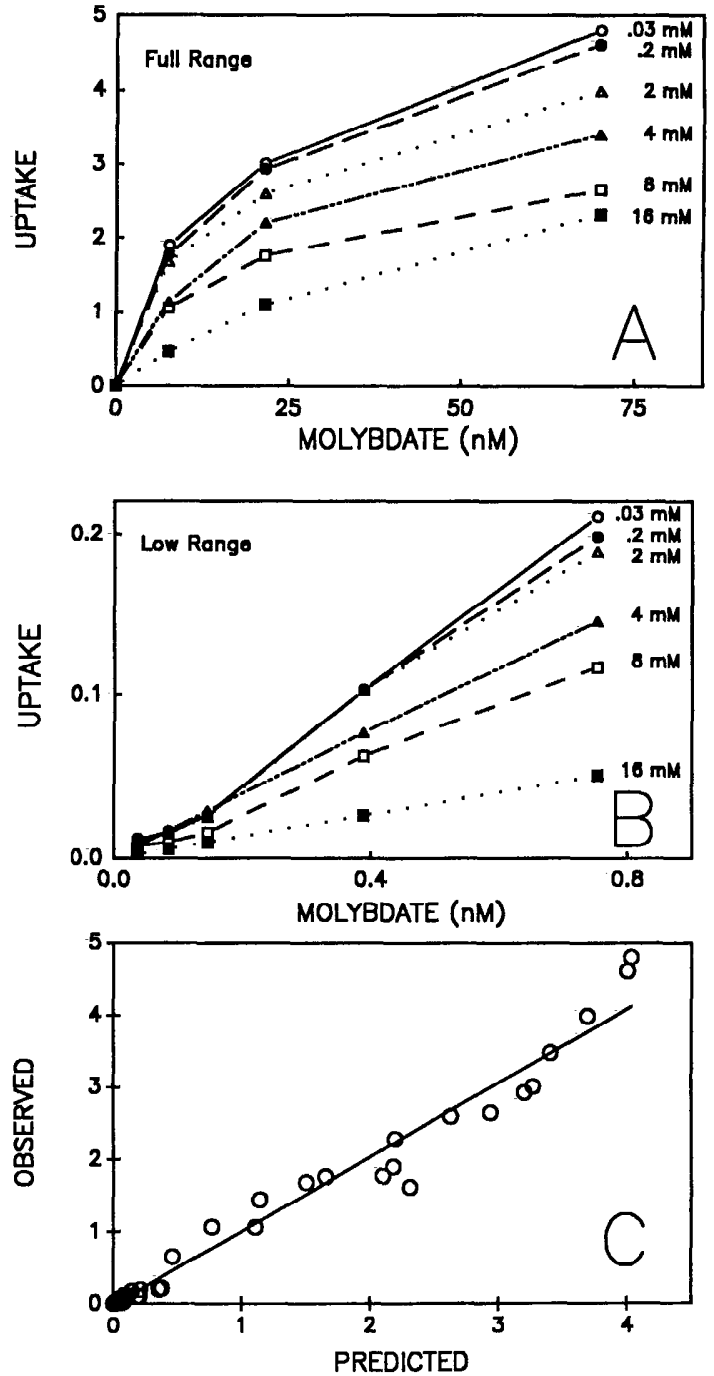

Fig. 5. Uptake of molybdate (pmol Mo liter ${ }^{-1} \mathbf{h}^{-1}$ ) as a function of molybdate concentration for Anabaena $c y$ lindrica (conditions given in Fig. 1) at six levels of sodium sulfate. In this experiment chlorophyll was $21 \mu \mathrm{g} \mathrm{liter}^{-1}$ and the $\mathrm{N}_{2}$-fixation rate was $100 \mathrm{nmol}^{\text {ethylene liter }}{ }^{-1}$ $\mathrm{h}^{-1}$. A. Full range of molybdate concentrations tested $(0$ $70 \mathrm{nM})$. B. Low range of molybdate concentrations $(0.01-$ $0.7 \mathrm{nM}$ ). C. Predicted molybdate uptake rate plotted against the observed rate for all six sulfate levels. Best-fit kinetic parameters are $K_{m}=8 \mathrm{nM} \mathrm{MoO}{ }^{2-}, V_{\max }=4.5$ pmol liter $^{-1}$ $\mathrm{h}^{-1}$, and $K_{i}-\mathrm{S}=2.2 \mathrm{mM} \mathrm{SO}_{4}{ }^{2-}$.

Although the $K_{i}-\mathrm{S}$ was broadly related to $K_{m}$ (linear regression; $r^{2}=0.86 ; P<0.0001$ ), the slope was far from unity $\left(5 \times 10^{5} \mathrm{~nm} \mathrm{~nm}^{-1}\right)$. These results imply that the uptake system exhibits a high degree of discrimination between sulfate and molybdate. Unlike the case for tungstate, the uptake system has several orders 


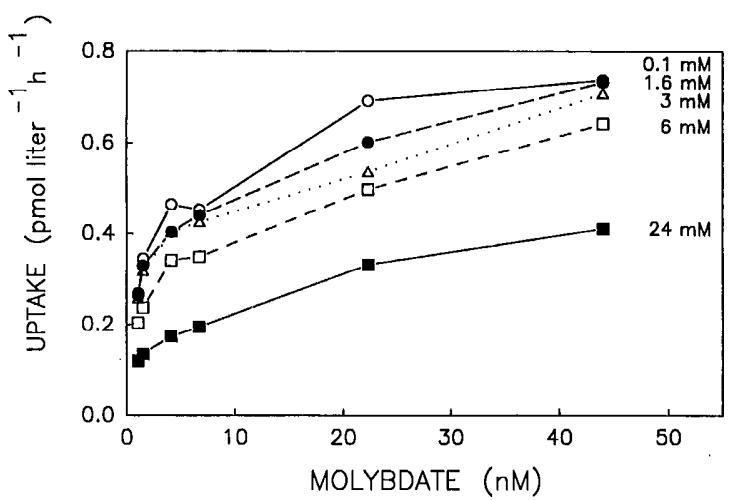

Fig. 6. Uptake of molybdate as a function of molybdate concentration for the natural phytoplankton community of eutrophic Chodikee Lake in the presence of five levels of added sodium sulfate. Best-fit kinetic parameters are $K_{m}=1.75 \mathrm{nM}, V_{\max }=0.5$ pmol liter $^{-1} \mathrm{~h}^{-1}$, and $K_{i}=$ $2 \mathrm{mM} \mathrm{SO}_{4}{ }^{2-}$. The chlorophyll concentration was $11.3 \mu \mathrm{g}$ liter ${ }^{-1}$ and the system was fixing nitrogen $(28 \mathrm{nmol}$ ethylene liter ${ }^{-1} h^{-1}$ ).

of magnitude greater affinity for molybdate than for sulfate.

Much of the variation in $K_{i}$-S could be explained by the sulfate concentration of the environment from which the sample was drawn (Fig. 7). A regression of $\log K_{i}-\mathrm{S}$ against $\log$ sulfate for the different systems (as in the case of Fig. 2) is highly significant and explains $78 \%$ of the variation in $\log K_{i}-\mathrm{S}(P<0.001)$. There was good correspondence between $K_{i}-\mathrm{S}$ and the environmental sulfate concentration, but the relationship is strongly curvilinear. As sulfate increases, the ratio of sulfate to $K_{i}$ increases. This ratio $\left(I: K_{i}\right)$ is the critical term in the equation for inhibition (Eq. 2) and as this ratio increases, the degree of inhibition increases. For low sulfate systems $I: K_{i}$ is negligible, $\sim 0.02$; in seawater the ratio approaches 2 so that the term $\left(1+I / K_{i}\right)$ from Eq. 2 roughly triples. The effect of this tripling on the uptake velocity is equivalent to tripling $K_{m}$ (e.g. dividing the affinity for molybdate by 3 ).

Biological turnover time of molybdate-Using the measured values of $V_{\max }, K_{m}, K_{i}$, $\left[\mathrm{MoO}_{4}{ }^{2-}\right]$, and $\left[\mathrm{SO}_{4}{ }^{2-}\right]$ we can calculate both ambient velocities of molybdate uptake $(v)$ and a biological turnover time for molybdate. Rates of ambient specific $v$ ranged from $\sim 0.01$ to 0.2 pmol Mo $(\mu \mathrm{g} \mathrm{Chl} a)^{-1} \mathrm{~h}^{-1}$ in the various environments, and low rates can be caused by either low concentrations of $\mathrm{MoO}_{4}{ }^{2-}$ or high concentrations of $\mathrm{SO}_{4}{ }^{2-}$. In general $v$ was well below $V_{\max }$ in most of the environments. The

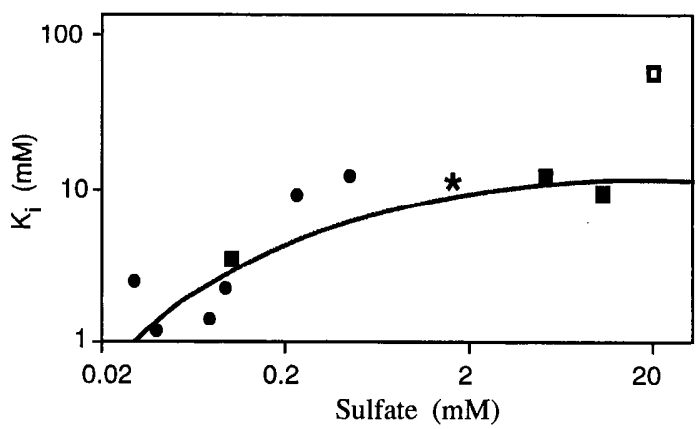

Fig. 7. Inhibition constants $\left(K_{i}-\mathrm{S}\right)$ for inhibition of the uptake of molybdate by sulfate. Freshwater lakes-o; freshwater, estuarine, and marine cultures $-\square$. $\square-$ The benthic cyanobacterium, Calothrix; *-the culture from Pyramid Lake (see cautionary note in Fig. 2). Equation for the line is $K_{i}=12 \times\left[\mathrm{SO}_{4}{ }^{2-}\right] /\left[0.3+\mathrm{SO}_{4}{ }^{2-}\right]$. When Calotrhix is included, $r^{2}=0.72$; when excluded, $r^{2}=0.77$.

one exception is the Nodularia culture from Pyramid Lake. Our limited data suggest that Pyramid Lake has exceedingly high molybdate concentrations (Table 2) and only moderate sulfate concentrations (Howarth et al. 1988b), allowing $V_{\max }$ to be approached.

The biological turnover time (molybdate concentration divided by the uptake rate) is the time it would take for the average dissolved molybdate molecule to be assimilated once, in well-illuminated surface waters at an assumed steady state, in the absence of new inputs. This turnover time is generally quite long, averaging $192 \mathrm{~d}$ for the freshwater lakes and $>3,000 \mathrm{~d}$ for marine systems. Within the group of lakes, however, turnover time can be quite variable and occasionally quite brief. For example, in September a cyanobacterial bloom in eutrophic Chodikee Lake, chlorophyll levels reached $70 \mu$ liter $^{-1}$ and $\mathrm{N}_{2}$ fixation was $145 \mathrm{nmol}$ ethylene liter $^{-1} \mathbf{h}^{-1}$. At this time the calculated turnover time was only $13 \mathrm{~d}$, suggesting the molybdate pool could potentially be depleted were the bloom to last for several weeks.

\section{Discussion}

One can question the validity of inferring real-world Mo uptake kinetics from culture studies. Organisms in culture can experience selective pressures often quite different from those in natural ecosystems and may well evolve enzyme systems that are different. Nonctheless, our data suggest that for a wide range of natural phytoplankton communities and phytoplankton cultures, the uptake of Mo 
has some common features, all indicative of an enzyme-mediated active transport phenomenon.

Uptake followed Michaelis-Menten saturation kinetics, indicating that the number of transport sites is finite. The rate of uptake is light-dependent, suggesting that energy is necessary for assimilation. An energy requirement is in agreement with the work of Steeg et al. (1986) who found that Anabaena oscillaroides concentrated Mo from the environment with accumulation factors of 500 to 3,000. Finally, we find that both tungstate and sulfate appear to be competitive inhibitors of molybdate transport. Although results similar to ours have been reported for heterotrophic bacteria, (e.g. Elliott and Mortensen 1975, 1976), mammalian intestinal loops (Cardin and Mason 1976), and tomato plants (Stout and Meagher 1948), our studies are the first to examine the kinetic properties of molybdate uptake and sulfate inhibition at ambient concentrations for a range of cyanobacteria or natural phytoplankton communities containing cyanobacteria.

There may be striking differences between the transport systems of cyanobacteria reported here and the heterotrophic bacteria previously studied. First of all, researchers working with heterotrophic $\mathrm{N}_{2}$-fixing bacteria have generally assayed molybdate uptake in the $\mu \mathrm{M}$ concentration range - a range much higher than usually found in natural waters. Such work has identified a molybdate uptake system for Clostridium which has $K_{m}$ near 5,000 $\mathrm{nM}$ and $K_{i}$ values for either tungstate or sulfate in the same range or higher (Elliott and Mortenson 1975). We previously reported, from measurements in a single lake, $K_{m}$ of $\sim 160 \mathrm{nM}-$ far lower than that for Clostridium (Cole et al. 1986). Because we did not have carrier-free molybdate in those experiments, we were adding considerably more molybdate (to $500 \mathrm{nM}$ ) than in the present set and overestimating $K_{m}$ and ( $V_{\max }$ as well) by as much as 100 -fold. Our new measurements for the same lake, Mirror Lake, suggest that the true $K_{m}$ is probably $\sim 1$ or 2 $\mathrm{nM}$ at most (Fig. 2). The average $K_{m}$ for all of the systems we investigated is only $\sim 28 \mathrm{nM}$ (although the range is quite large) and $\sim 15 \mathrm{nM}$ for the freshwater systems. Thus, organisms living in these relatively low molybdate environments have a molybdate transport system that is effective in the environmental concentration range.
An organism equipped with a transport system such as the Clostridium studied by Elliott and Mortensen (1975) would be able to transport molybdate at extremely slow rates in most natural waters or sediments, based on the kinetic data they report. In fact, the ecological significance of such low-affinity transport systems is difficult to comprehend because molybdate concentrations rarely exceed $200 \mathrm{nM}$ in most natural waters (Howarth et al. 1988b; Marino et al. 1990). Some heterotrophic bacteria may have both a low- and a high-affinity transport system for molybdate. Maier et al. (1987) and Graham and Maier (1987) studied Mo metabolism for Bradyrhizobium japonicum and found a high-affinity transport system with a $K_{m}$ of $11 \mathrm{nM}$ (e.g. comparable to the data we report here) and a low-affinity system with a $K_{m}$ of $900 \mathrm{nM}$. Mutants that lacked the high-affinity molybdate transport systems were unable to fix nitrogen at molybdate concentrations as high as 1,000 nM (Maier et al. 1987).

Other studies generally concur that tungstate is a powerful inhibitor of molybdate transport (Shah et al. 1984 and references therein). Our work here with cyanobacteria and natural phytoplankton communities agrees. We found that the $K_{i}$ for tungstate was in exactly the same range as the $K_{m}$ for molybdate, indicating nearly mole-for-mole inhibition. In the coastal ocean, reported tungstate concentrations are $\sim 100$-fold lower than molybdate concentrations (Pope et al. 1980; Chen and Yang 1984) and in the open ocean 2,000-fold lower (Sohrin et al. 1987), so tungstate would not be a significant inhibitor in seawater. We know of relatively few data on tungstate concentrations in freshwater; it is generally held that levels rarely are $>5 \mathrm{nM}$. Molybdate concentrations, however, are often this low (see Howarth et al. $1988 a$ ), suggesting some potential for inhibition by tungstate, but we know of no direct evidence.

The inhibitory effect of $\mathrm{SO}_{4}{ }^{2-}$ on $\mathrm{MoO}_{4}{ }^{2-}$ uptake is probably more complex than the effect of tungstate. Cells have a substantial requirement for $\mathrm{S}$ which can be met by the assimilation of sulfate (Cuhel et al. 1982). Thus the inhibitor also contains an essential element for growth. At low $\left[\mathrm{SO}_{4}{ }^{2-}\right]:\left[\mathrm{MoO}_{4}{ }^{2-}\right]$ ratios (relative to the need for $\mathrm{S}$ and $\mathrm{Mo}$ ) one might expect no inhibition since cells would need both elements. This dual role of sulfate may explain the increase in $K_{i}$ as sulfate increases 


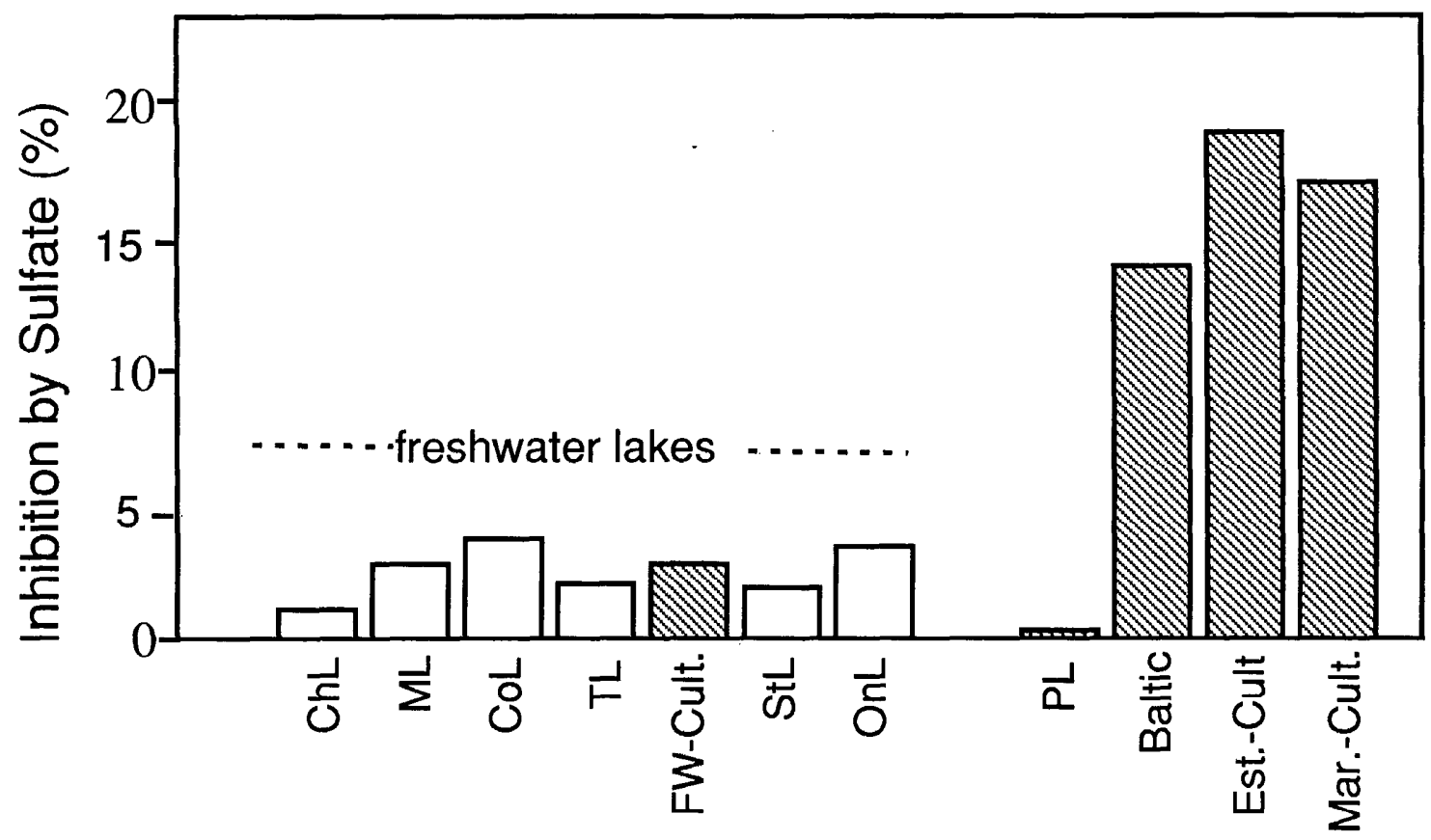

Fig. 8. Inhibition of molybdate uptake velocities at ambient sulfate and molybdate concentrations: We calculated the rate at which molybdate could be assimilated in each system if the system had no sulfate and used this theoretical "no sulfate" rate to compute how much the actual ambient rate was diminished due to inhibition by sulfate. See cautionary note concerning Pyramid Lake in Fig. 2. Symbols: ChL-Chodikee Lake; ML-Mirror Lake; CoL-Copake Lake; TL-Taghkanic Lake; FW-Cult. - average of freshwater cultures; StL-Stissing Lake; OnL-Oneida Lake; PLNodularia from Pyramid Lake; Baltic-Nodularia from the Baltic Sea; Est.-Cult. - average of estuarine cultures; Mar.Cult-average of marine cultures.

from low to intermediate levels and the leveling-off of $K_{i}$ with further increases in sulfate (e.g. Fig. 7). This duality may lead to complicating physiological adaptations in some cases.

Our results suggest that sulfate will inhibit molybdate transport in cyanobacteria and appears to do so competitively. However, sulfate is not a mole-for-mole inhibitor; cells are able to discriminate between sulfate and molybdate to a large degree. For example, if we use our average values for $K_{m}, K_{i}$, and $V_{\max }$ and assume a typical molybdate concentration of $4 \mathrm{nM}$ for freshwaters, we find a sulfate concentration of nearly $8 \mathrm{mM}$ would be required to inhibit molybdate uptake by $50 \%$, which is consistent with our earlier observations and reasoning that sulfate is not a major impediment to Mo uptake in freshwaters (Howarth and Cole 1985; Howarth et al. 1988a). Thus at reasonably low molybdate concentrations the ratio (by moles) of $\left[\mathrm{SO}_{4}{ }^{2-}\right]:\left[\mathrm{MoO}_{4}{ }^{2-}\right]$ causing $50 \%$ inhibition would be $\sim 2 \times 10^{6}: 1$. The $\left[\mathrm{SO}_{4}{ }^{2-}\right]:\left[\mathrm{Mo}_{4}{ }^{2-}\right]$ ratio ranges from $10^{4}$ to $10^{6}$ in natural systems (Marino et al. 1990) and although organisms can discriminate to some extent between molybdate and sulfate, molybdate uptake is, nevertheless, affected.

The kinetic parameters $K_{m}$ and $K_{i}$ appear to vary with the molybdate and sulfate concentrations of the systems, and molybdate and sulfate also covary. These factors tend to offset the inhibition by sulfate to some extent, especially at intermediate sulfate concentrations, but do not eliminate it at high sulfate concentrations. To illustrate this point we have plotted the percent inhibition, caused by the ambient sulfate concentration, of the velocity of molybdate uptake at the ambient molybdate concentration (Fig. 8). In this calculation we have taken into account the relationships between $K_{m}$ and molybdate and $K_{i}$ and sulfate (Figs. 2 and 7). In freshwater lakes ambient sulfate concentrations inhibit the uptake velocities by only $1-4 \%$. For estuaries and in the ocean, however, molybdate uptake would be inhibited by $\sim 20 \%$ compared to what the uptake would be in the absence of sulfate. If our kinetic parametcrs are extrapolated to saline 
lakes with high $\left[\mathrm{SO}_{4}{ }^{2-}\right]:\left[\mathrm{MoO}_{4}{ }^{2-}\right]$ ratios such as reported by Marino et al. (1990), this inhibition, using the same calculation, could be $>70 \%$.

These results support, at least in part, the first part of our original hypothesis (Howarth and Cole 1985): Mo availability is not simply a function of Mo concentration because sulfate can inhibit its assimilation. However, we find the kinetic parameters indicate that this inhibition will be marked only in ecosystems, such as some saline lakes, that have very high $\left[\mathrm{SO}_{4}{ }^{2-}\right]:\left[\mathrm{MoO}_{4}{ }^{2-}\right]$ ratios; the inhibition would be only moderate in seawater. The second part of our original hypothesis is that low availability of Mo caused by high ratios of $\left[\mathrm{SO}_{4}{ }^{2-}\right]$ : $\left[\mathrm{MoO}_{4}{ }^{-2}\right]$ in oxic waters can limit the activity of planktonic $\mathrm{N}_{2}$-fixing organisms. Whether this is correct cannot be inferred from the data presented here alone, since factors other than Mo availability can affect $\mathrm{N}_{2}$-fixing organisms (Howarth et al. 1988b; Vitousek and Howarth 1991; Paulsen et al. 1992). Also, cells may pay an energetic cost for making molybdate-assimilating enzymes that discriminate well between sulfate and molybdate. If this cost is significant it could partially limit rates of $\mathrm{N}_{2}$ fixation even though the cell-specific rate of molybdate uptake were only slightly affected.

\section{References}

Caraco, N., A. Tamse, O. Boutros, and I. Valiela. 1987. Nutrient limitation of phytoplankton growth in brackish coastal ponds. Can. J. Fish. Aquat. Sci. 44: $473-476$

Cardin, C. J., And J. Mason. 1976. Molybdate and tungstate transfer in rat ileum: Competitive inhibition by sulphate. Biochim. Biophys. Acta 455: 937-946.

Chen, L., AND S. YANG. 1984. The distribution of tungsten in Amoy Bay. Haiyang Xuebao 6: 701-708.

Cole, J. J., R. W. HowarTh, S. S. Nolan, AND R. Marino. 1986. Sulfate inhibition of molybdate assimilation by planktonic algae and bacteria: Some implications for the aquatic nitrogen cycle. Biogeochemistry 2: 179196.

Cuhel, R., C. D. TAYlor, and H. W. Jannasch. 1982. Assimilatory sulfur metabolism in marine microorganisms: Considerations for the application of sulfate incorporation into protein as a measurement of natural population protein synthesis. Appl. Environ. Microbiol. 43: 160-168.

Currie, D. 1982. Estimating Michaelis-Menten parameters: Bias, variance and experimental design. Biometrics 38: 907-920.

ELlIOTT, B. B., AND L. E. MORTENSON. 1975. Transport of molybdate by Clostridium pasteurianum. J. Bacteriol. 124: 1295-1301.
—_ AND —. 1976. Regulation of molybdate transport by Clostridium pasteurianum. J. Bacteriol. 127: 770-779.

FoGG, G. E., AND M. WOLFE. 1954. Nitrogen metabolism of blue-green algae. Symp. Soc. Gen. Microbiol. 4: 99-125.

Gorham, P. R., J. MCLachlan, U. T. Hammer, and W. K. KIN. 1964. Isolation and culture of toxic strains of Anabaena flos-aquae. Int. Ver. Theor. Angew. Limnol. Verh. 15: 796-804.

Graham, L., AND R. J. MAIER. 1987. Variability in molybdenum uptake activity in Bradyrhizobium japonicum strains. J. Bacteriol. 169: 2555-2560.

Guillard, R. R. L. 1975. Culture of phytoplankton for feeding marine invertebrates, p. 29-60. In W. L. Smith and M. H. Chanley [eds.], Culture of marine invertebrate animals. Plenum.

Holm-Hansen, O., and B. RiemanN. 1978. Chlorophyll- $a$ determination: Improvements in methodology. Oikos 30: 438-477.

Howarth, R. W. 1988. Nutrient limitation of net primary production in marine ecosystems. Annu. Rev. Ecol. Syst. 19: 89-110.

nitrogen limitation and phytoplankton growth in natural waters. Science 229: 653-655.

- , R. Marino, ANd J. J. Cole. 1988a. Nitrogen fixation in freshwater, estuarine, and marine ecosystems. 2. Biogeochemical controls. Limnol. Oceanogr. 33: $669-697$.

$\longrightarrow,-$, J. LANE, AND J. J. COLE. 1988b. Nitrogen fixation in freshwater, estuarine, and marine ecosystems. 2. Rates and importance. Limnol. Oceanogr. 33: $688-701$.

KRATZ, W. A., AND J. MYERS. 1955. Nutrition and growth of several blue-grcen algae. Am. J. Bot. 42: 282-287.

Maier, R. J., L. Graham, R. G. Keefe, T. Phil, and E. SMITH. 1987. Bradyrhizobium japonicum mutants defective in nitrogen fixation and molybdenum metabolism. J. Bacteriol. 196: 2548-2554.

Manheim, F. T., AND S. LANDERGRen. 1978. Molybdenum, Section 42, p. B-2 to O-2. In Handbook of geochemistry. V. 2-4. Springer.

Marino, R., R. W. Howarth, J. Shamess, and E. Prepas. 1990. Molybdenum and sulfate as controls on the abundance of nitrogen-fixing cyanobacteria in saline lakes in Alberta. Limnol. Oceanogr. 35: 245-259.

OHKI, K., J. G. Reuter, AND Y. FujITA. 1986. Cultures of the pelagic cyanophytes, Trichodesmium erythraeum and $T$. theibautii in synthetic medium. Mar. Biol. 91: 9-13.

PAERL, H. W. 1988. Nuisance phytoplankton blooms in coastal, estuarine, and inland waters. Limnol. Oceanogr. 33: 823-847.

- , K. M. Crocker, And L. E. Prufert. 1987. Limitation of nitrogen fixation in coastal marine waters: Relative importance of molybdenum, iron, phosphorus, and organic matter availability. Limnol. Oceanogr. 32: 525-536.

Paulsen, D. M., H. W. Paerl, AND P. E. Bishop. 1992. Evidence that molybdenum-dependent nitrogen fixation is not limited by high sulfate concentrations in marine environments. Limnol. Oceanogr. 36: 13251334. 
Pope, M. T., E. R. Still, and R. J. P. Williams. 1980. A comparison between the chemistry and biochemistry of molybdenum and related elements, p. 3-40. In M. P. Coughlan [ed.], Molybdenum and molybdenum containing enzymes. Pergamon.

Robson, R. L., AND OTHERs. 1986. The alternative nitrogenase of Azotobacter chroococcum is a vanadium enzymc. Nature 322: 388-390.

RudolPh, B., AND H. J. Fromm. 1983. Plotting methods of analyzing enzyme rate data, p. 53-74. In D. Purich [ed.], Contemporary enzyme kinetics and mechanism. Academic.

Shah, V. K., R. A. Ugalde, J. Imperial, ANd W. J. Brill. 1984. Molybdenum in nitrogenase. Annu. Rev. Biochem. 53: 231-257.

SOHRin, Y., K. Isshihi, AND T. Kuamtot. 1987. Tungsten in North Pacific waters. Mar. Chem. 22: 95-103.

Statistical Graphics CoRP. 1987. Statgraphics version 2.6 .
Steeg, P. F., P. J. Hanson, And H. W. Paerl. 1986. Growth-limiting quantities and accumulation of molybdenum in Anabaena oscillaroides (Cyanobacteria). Hydrobiologia 140: 143-147.

Stewart, W. D. P., G. P. Fitzgerald, ANd R. H. Burris. 1967. In situ studies on $\mathrm{N}_{2}$ fixation using the acetylene reduction technique. Proc. Natl. Acad. Sci. 58: 2071-2078.

Stout, P. R., And W. R. Meagher. 1948. Studies of the molybdenum nutrition of plants with radioactive molybdenum. Science 108: 471-473.

Virousek, P. M., AND R. W. HowarTh. 1991. Nitrogen limitation on land and the sea. How can it occur? Biogeochemistry 13: 87-115.

Submitted: 27 August 1991 Accepted: 30 June 1992 Revised: 11 August 1992 